\title{
TEACHING A PRONUNCIATION PROBLEM
}

Jeris E. Strain

University of Michigan

1. There are without doubt a vast number of ways to teach a given pronunciation problem. The general approach and methodology outlined here are certainly not new; as a matter of fact, they have been employed to teach English as a Foreign Language at the English Language Institute for over two decades. At the same time, however, knowledge of this point of view has been confined to a relatively small group as attested by the lack of literature available to the interested reader. Our main purpose here is to fill in a small portion of this gap.

2. Our task is to teach the sound system of a foreign language. To do so we attempt to bring as much linguistic knowledge as possible to bear on the "what" of our task and complement it with the best "how" ideas that are known to us.

In defining our task, we take certain propositions for granted, propositions based on conclusions reached in the scientific study of language; namely:

(a) that the sound system of a language is made up of a certain rather small set of elements which function significantly as carriers of the message (usually called phonemes).

(b) that the sound systems of two languages are never the same.

(c) that pronunciation problems can be predicted at least in part by comparing the native-language sound system with that of the target language.

(d) that skill in pronunciation consists of a set of automatic habits involving the hearing organs and the speech organs, plus the ability not only to recognize significant sounds in a stream of speech but also to react to them in an acceptable manner.

(e) that a prerequisite to developing the ability to produce 
significant sounds is development of the ability to recognize the significant sounds.

(f) that learning to speak a language should precede learning to read and write it.

Pedagogy, on the other hand, provides us with the procedure to be outlined below, based on these important principles:

(a) that spoken language habits can be most effectively developed by drilling.

(b) that the conscious drilling of a learning point during an exercise should gradually become unconscious drilling by shifting the learner's attention to a point that is related but irrelevant to the learning point, such that the point being learned comes to be produced automatically.

(c) that learning the few but essential points of the target sound system and developing the necessary automatic habits can best take place with a restricted number of vocabulary items.

(d) that to be effective, learning must take place with regard for meaning in a contextual setting, not in isolation.

(e) that classroom procedure should consist of a minimum of explanation and a maximum of practice.

3. Application of these "what" and "how" principles leads us to two problems: (1) the nature of the phonological problem that we intend to teach and (2) the method to be followed in teaching it. Suppose we take as an example the problem of teaching the English high-front vowels to a speaker of Persian.

3.1. Phonetic studies provide the following information about the English and Persian sound systems:

(a) Both English and Persian have a higher high-front tense unrounded vowel which might be designated /i/; the English vowel, however, is usually followed by a high-front glide, giving the contrast of English [iy] and Persian [i].

(b) English also has a lower high-front lax backed unrounded vowel which may be designated /1/; Persian has no counterpart. 
(c) The following examples illustrate the probiem:

\begin{tabular}{cll} 
Persian & \multicolumn{2}{c}{ English } \\
[i] & [iy] & \multicolumn{1}{c}{ [I] } \\
/? il/ 'tribe' & eel & ill \\
/?ín/ 'this' & --- & in \\
/pic/ 'screw' & peach & pitch \\
/bid/ 'willow' & bead & bid \\
/si'/ 'thirty' & see &.-- \\
/kí/ 'who' & key & ---
\end{tabular}

For teaching purposes the above information may be summarized from the point of view of (a) recognition problems and (b) production problems.

(a) The Persian speaking student will have difficulty

(1) in distinguishing between English [iy] and [I] and (2) in hearing and recognizing [I].

(b) The Persian speaking student must learn (1) to produce the high-front glide found in English [iy] and (2) to lower and back his tongue to produce [I].

3.2. One procedural method that might be followed in teaching this pronunciation problem is as follows:

GOAL

1. Attention pointer

2. Focus attention on the problem-area

\section{TECHNIQUE}

1. Teacher calls student's attention to the learning point.

2. Student just listens to teacher's pronunciation of items containing the target sounds.

3. Sharpen recognition. 3. Student tries to recognize each sound in different consonantal environments.

4. Generalize

4. Teacher points out and emphasizes the significant features that must be mastered.

5. Produce new sounds 5. a. Student mimics teacher's production of one-syllable items.

b. Teacher pronounces items containing one of the sounds; student produces the opposite sound. 
c. Student mimics teacher's pronunciation of two-syllable items.

d. Student mimics teacher's pronunciation of longer utterances.

6. Check perception

7. Drill

6. Teacher presents minimal sentences; students try to recognize the new sounds.

7. a. Teacher presents substitution drills; students are cued to supply items containing one of the new sounds.

b. Teacher presents pattern practices, the frames containing frequently missed items; student again gives a cued response.

8. Reinforce and stabilize sounds taught

8. Student practices in laboratory, at home, or both.

Notice that the first seven steps can be broken down in the following fashion: Step 1 introduces the lesson; Steps 2, 3, 6 deal with recognition; Step 4 deals with brief, concise statements based on linguistic insights; Steps 5,7 deal with production. In teaching, a minimum of time should be spent on Steps 1-4 and a maximum of time on Steps 5-7; Step 8 would probably take place outside of the classroom. At each step, accuracy should be continually emphasized and demanded.

4. An actual lesson plan might be as follows. (Only the teacher's role will be illustrated.)

4.1. Step 1. Attention pointer. Using pictures, actions, or some other device, the teacher calls the students' attention to a minimal contrast between the new sounds-for example, 'sheep' and 'ship'-and designates each with an appropriate symbol on the blackboard-for example [iy] and [I] . Henceforth, the symbols may be referred to by the teacher as a cue and point of reference.

4.2. Step 2. Focus attention. 
a) Listen to words containing this sound. (Teacher points to [iy] on the blackboard; students listen and do not repeat.)

$\begin{array}{ll}\text { sheep } & \text { sheep } \\ \text { leave } & \text { leave } \\ \text { he's } & \text { he's }\end{array}$

b) Listen to words containing this sound (Teacher points to [I]);

$\begin{array}{ll}\text { ship } & \text { ship } \\ \text { live } & \text { live } \\ \text { his } & \text { his }\end{array}$

c) Now listen to the contrast (teacher points to the appropriate symbols):

$\begin{array}{llll}\text { sheep - } & \text { ship } & \text { sheep } & \text { ship } \\ \text { leave - live } & \text { leave } & \text { live } \\ \text { he's - his } & \text { he's } & \text { his }\end{array}$

d) Can you hear the difference? (The students will probably say 'yes', which leads into Step 3.)

Notes: 1 . Words containing problem consonants that have not yet been taught should not appear here or anywhere in the lesson; for example, $/ \theta /, / \mathrm{d} /, / \mathrm{r} /, / \mathrm{w} /$.

2. The focus is at this point on the two target sounds as such, without reference to the meanings of the words.

3 . The choice of items may be limited to minimal pairs; nonsense words might be used, but if minimal pairs are available, they should be used.

4.3 Step 3. Sharpen Recognition. (The students have replied that they can distinguish between [iy] and [r] .)

a) Then identify the vowel sound in these words:

b) Let's call [iy] No. 1, and [I], No. 2. (Teacher writes the numbers above the symbols.) If the vowel sound is [iy] say "one"; if it is [I] say "two".

c)

he's
sheep
his

d)

is
if
in

(2)

\begin{abstract}
ship
leave

live

seem

seen

$\sin$

he's
\end{abstract}

(2)

ship
he's
his
key
did
miss
she

Notes: 1. Items used should provide a wide variety of consonant environments. 
2. Minimal pairs need not be used; words that are frequently mispronounced should be included.

3 . The focus is still on the target sounds.

4. The exercise should begin with choral response for three or four items and then switch to individual responses.

\subsection{Step 4. Generalize.}

a) Fine! Now tell me how [iy] and [I] are different.

b) Say "he's" and "his" to yourself. The front part of the tongue isn't the same, is it?

c) When we say [iy] the tongue is high and close to the top of the mouth; when we say [1] the tongue is low and toward the middle of the mouth. (Reference to a cross-section of the mouth is quite useful.)

d) In addition, English [iy] is usually long and followed by a gliding movement of the tongue.

e) Pronounce [iy] after me: [iy-iy-iy....]

f) Pronounce $[\mathrm{I}]$ after me: $[\mathrm{I}-\mathrm{I}-\mathrm{I} \ldots]$

Notes: 1. This step should be brief and to the point; long explanations are unnecessary and a waste of time.

2. The significant feature or features to be mastered should be emphasized.

\subsection{Step 5, Develop Flexibility.}

a) Now let's practice.

b) Pronounce these contrasts after me:

$\begin{array}{llll}\text { sheep } & \text { ship } & \text { ship } & \text { sheep } \\ \text { he's } & \text { his } & \text { his }- \text { he's } \\ \text { leave } & \text { live } & \text { live }- \text { leave } \\ \text { seen } & \text { sin } & \text { sin }- \text { seen } \\ \text { deed }- \text { did } & \text { did }- \text { deed }\end{array}$

c) Pronounce these words after me:

$\begin{array}{llll}\text { beat } & \text { it } & \text { me } & \text { fill } \\ \text { bit } & \text { is } & \text { him } & \text { in } \\ \text { live } & \text { tea } & \text { see } & \text { did } \\ \text { leave } & \text { he } & \text { itch } & \text { she }\end{array}$

d) Pronounce a word with the opposite sound: If I say 'beet', you say 'bit'.

$\begin{array}{llll}\text { live } & \text { he's } & \text { seat } & \text { leave } \\ \text { sheep } & \text { Tim } & \text { deed } & \text { eat }\end{array}$




$\begin{array}{llll}\text { beat } & \text { did } & \text { feel } & \text { seen } \\ \text { it } & \text { sin } & \text { ship } & \text { bit }\end{array}$

e) Pronounce these phrases after me:

$\begin{array}{lll}\text { [iy-iy] } & {[1-I]} & \text { Contrast } \\ \text { she eats } & \text { it did } & \text { his feet } \\ \text { he sees } & \text { it is } & \text { he did } \\ \text { she sees } & \text { his lip } & \text { it's tea } \\ \text { he eats } & \text { his ship } & \text { it's me }\end{array}$

f) Pronounce these sentences after me:

$\begin{array}{ll}\text { [iy-iy. . ] } & \text { 1. He's eating meat. } \\ \text { [I-I-I ..] } & \text { 2. It's his fish. } \\ \text { (contrast) } & \text { 3. Give me his key. } \\ \text { (contrast) } & \text { 4. Give me his tea. } \\ \text { (contrast) } & \text { 5. Did she see it? }\end{array}$

Notes: 1. Using primarily the target sounds creates several restrictions in making up exercises; nevertheless, utterances of this type can be very effective in developing speech-organ flexibility.

2. A problem is the need of vocabulary items; even though the focus is on production of the sounds as such, useful and meaningful items should be the rule.

3. Each exercise may begin with choral response but should soon switch to individual responses.

\subsection{Step 6. Check Perception.}

a) Tell me if these sentences sound the same or different: (Observe the intonation peaks-stressed words.)

1. He bit me. He béat me.

(Different)

2. Tim béat me. Tim béat me. (Same)

3. Did he líve? Did he léave?

4. Fîll it. Fîl it.

5. Please féel it. Please féel it. (Same)

b) Which of these sentences are the same?

1. He bít me. He bít me. He béat me.

2. Féel it. Fill it. Féel it.

3. Did he líve? Did he líve? Did he líve?

4. Tím beat me. Tím beat me. Tím bit me.

5. Pléase fill it. Pléase feel it. Pléase feel it. 
Notes: 1. Notice that the loud stress has been put on the key words at first and then moved; perception may thus be checked in both stressed and unstressed positions.

2. There should be not more than one difference in each set of utterances, and that difference should pertain to the target sounds.

\subsection{Step 7. Drill.}

a) Complete this sentence: (Teacher may use pictures or charts to cue the responses.)

b) It's his

$\begin{array}{llll}\text { ship } & \text { lip } & \text { chin } & \text { meat } \\ \text { sheep } & \text { tea } & \text { knee } & \text { milk } \\ \text { key } & \text { cheek } & \text { fish } & \end{array}$

c) Give me his

$\begin{array}{lll}\text { key } & \text { meat } & \text { sheep } \\ \text { dish } & \text { fish } & \text { milk } \\ \text { tea } & \text { ship } & \end{array}$

d) Did she it?

$\begin{array}{ll}\text { eat } & \\ \text { fill } & \text { leave } \\ \text { see } & \text { feel } \\ \text { fix } & \text { kiss }\end{array}$

Notes: 1. The major aim in each of these exercises is correct pronunciation of the sentence frame first and of the cued items second.

2. Meaning is essential at this point, both on a structural and lexical level; charts, pictures, gestures, and actions are a few techniques that could be used to provide cues to the meaning.

3. Exercises of this type could be used to expand the student's vocabulary while mastery of structural patterns are being reinforced; that is, "Tim is _ -ing." could form the basis for another exercise, providing the $/ \mathrm{g} /$ problem has been taught. "Please" could be used on the production level, providing the initial consonant cluster has been taught. The question structure "Is it (his) __ ?" could be used for still another exercise.

4. Very frequent and often-mispronounced items containing the target sounds should be worked into the structural frames and drilled until they are automatically pronounced correctly.

4.8. Step 8. Reinforcement. 
a) Since this step may take place in a language laboratory or out of class, a brief review of the target sounds should be provided first. One procedure would be to quickly go over Steps 2 (presentation), 5 (mimicry production), and 6 (recognition check) again.

b) If a tape recorder is available, oral exercises on tape can be correlated with pictures in a workbook. The pictures should be accompanied by regular spelling as well as the special alphabet used for teaching. For example:

Picture 1.

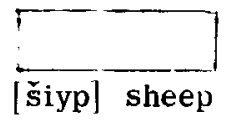

Picture 2 .

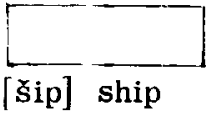

Tape voice: "It's his Student:

Tape voice: "Sheep. It's his sheep." Student: (Repeats.)

Tape voice: Student: "Picture 2." "Ship. It's his ship."

Tape voice: "Ship. It's his ship." Student:
(Repeats.)

c) A major point in stabilizing the target sounds is to correlate them with their usual orthographic representation; therefore, a statement in the workbook summing up the various spellings is in order. For example: "Note that in pictures $1,3, \ldots$ Vowel No. 1 [iy] is spelled: ee, ey, ea, etc., and that in pictures $2,3, \ldots$ Vowel No. $2[\mathrm{I}]$ is always spelled $i$.

d) Pattern practices of the type in Step 7, but using words in regular spelling as cues, might be used at this point:

1. sheep

2. key
Tape voice:

Student:

Tape voice:

Student:

Tape voice:

Student:

Tape voice:

Student:
"1. Is it his

"Sheep. Is it his sheep?"

"Sheep. Is it his sheep?" (Repeats.)

"Two."

"Key. Is it his key?"

"Key. Is it his key?"

(Repeats.)

e) Paper and pencil exercises to check production might be as follow's:

1. Students circle the correct answer.

i) I believe he'll

ii) Is the

goin going to tip? sheep $\begin{array}{ll}\text { live } & \text { (leave) } \\ \text { ship } & \text { (ship) }\end{array}$ 
2. Students circle the correct answer.
i) $\mathrm{A}$ is a boat.
sheep
ship
(ship)
ii) This is ship.
he's
iii) $A$
is an animal.
sheep ship
(his)
(sheep)

f) A short paragraph or conversation using the target sounds as much as possible (to be memorized) completes the lesson plan.
A. Did she see it?

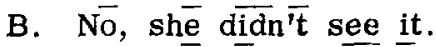
A. Is it his sheep?
B. Y Y $\bar{s}$, it is his sheep.

5. In drafting this lesson plan, we have assumed that about twenty minutes could be devoted to teaching the one problem-area and that other class periods would be devoted to learning points of structure and vocabulary. There is, of course, an inescapable degree of overlap between pronunciation, structure, and vocabulary.

Depending on the level of the students and the competence of the instructor, the lesson plan outlined above could be either expanded or reduced. It may be that the plan given is more elaborate and detailed than necessary; but this was our intention. Regardless of how such a plan is adapted or changed, it is important not to deviate too much from the "what" and "how" principles underlying the approach and to make each step in the process relate clearly to the basic goals toward which the methodology is directed. 